\title{
Serum Level and Genetic Polymorphism of Secretary Phospholipase A2-IIA in Alzheimer's Disease
}

\section{Hakimi S ${ }^{1}$, Marjani $\mathbf{A}^{2 *}$ and Khajeniazi $\mathbf{S}^{3}$}

${ }^{1}$ Research Committee, Gorgan Faculty of Medicine, Golestan University of Medical Sciences, Gorgan, Golestan Province, Iran

${ }^{2}$ Metabolic Disorders Research Center, Department of Biochemistry and Biophysics, Faculty of Medicine, Golestan University of Medical Sciences, Gorgan, Golestan

Province, Iran

${ }^{3}$ Department of Medical Cellular and Molecular Research Center, Golestan University of Medical Sciences, Gorgan, Golestan Province, Iran

\section{Abstract}

Background: Alzheimer's disease (AD) is a neurodegenerative disease and is the most common because of late life dementia. Alteration of Secretary Phospholipase A2-IIA (sPLA2-IIA) may have an important role in membrane phospholipids metabolism and the pathogenesis of $A D$. The aim of our study was to determine serum levels and genetic variant of SPLA2-IIA in Alzheimer's disease and compare to controls.

Methods: This study included 40 healthy unrelated individuals and 40 patients with AD. Serum levels and the polymorphisms of sPLA2-IIA enzyme were determined.

Results: In Alzheimer patients, the CC genotype and $C$ allele frequencies of enzyme were significantly lower while the $C G$ and $G G$ genotypes and $G$ allele frequencies of enzyme were significantly higher than controls. The mean concentration and mean rank of enzyme for CC genotype significantly were lower while the $C G$ and $G G$ genotypes of enzyme were significantly higher than controls.

Conclusion: The effect of different gene polymorphisms for the incident of $A D$ is still unclear. We determined gene polymorphisms of SPLA2-IIA which may relate to AD. It can be suggest that a single or combination of gene polymorphisms have possible effect for development of $A D$. Further studies are needed to research the functional roles of SPLA2-IIA in the context of AD.

Keywords: sPLA2-IIA; Polymorphism; Alzheimer's disease

\section{Introduction}

Alzheimer's disease (AD) affects more than 27 million individuals and may reach to 86 million people by the year 2050. Late-onset AD forms more than $90 \%$ of all $\mathrm{AD}$ cases which signs of disease appear after the age of 65 years [1]. The $\mathrm{AD}$ is characterized by loss of synapses and neurons and decrease in brain volume [2]. Alzheimer's disease $(\mathrm{AD})$ is a neurodegenerative disease and is the most common because of late life dementia [3]. The most cases of $\mathrm{AD}$ are thought to be occasional. Alzheimer's disease is a multifactorial disease. The pathology of $\mathrm{AD}$ may affect by lifestyle, genetic and environmental factors. Genetic factors, seems to play an important role [4]. There are over 30 different types of PLA2s in different mammalian cells. These different types may have role in regulating of specific cell functions. The most important PLA2 family is separated into cytosolic PLA2 (cPLA2), calcium-independent PLA2 (iPLA2), and secretary PLA2 (sPLA2) [5].

Secretary phospholipase A2-IIA (sPLA2-IIA) catalyze the splitting of fatty acids from the sn-2 position of glycerophospholipids and produce a non-esterified fatty acid and lysophospholipids. sPLA2s take part in digestion of phospholipids, cell membranes remodeling and host defense. There are more than 19 different isoforms of mammalian PLA2 [6]. The human sPLA2-IIA consists of 144 amino acids [7]. The gene of human sPLA2-IIA is located on chromosome 1p35. sPLA2IIA mRNA is shown in all part of brain region. It is highly and lowly expressed in the brainstem and midbrain, and cerebellum and corpus striatum, respectively [8]. SPLA2 is expressed in the brain of $A D$ patients [9]. Many studies have indicated that there are an association between increased levels of secretory phospholipases (sPLA2s) and coronary heart disease (CHD), rheumatoid arthritis and asthma [1012]. Secretary phospholipase A2-IIA is the most expressed of the sPLA2 proteins. It is expressed in the liver (secretion into the blood stream) and in the arterial wall [13]. A number of other studies have shown the physiological and pathological roles of PLA2 in AD [14-19]. Many studies have revealed the association of genetic polymorphisms with AD pathophysiology, but the results were consistent [20,21]. Phospholipids in Brain are an important place for the occurrence of interaction between genes and environment [22]. It has been reported that Brain PLA2 activity decreased in patients with AD $[23,24]$ and decreased activity of PLA2 was associated to earlier onset of dementia, earlier age at death [24]. In vitro study has shown that decreased PLA2 activity has an important role in membrane phospholipids metabolism alterations and the pathogenesis of $\mathrm{AD}$ [25]. The aim of our study was to determine genetic variant of sPLA2-IIA and its serum levels of enzyme in Alzheimer's disease and compare to control groups.

\section{Materials and Methods}

\section{Sample}

This study included 40 healthy unrelated individuals (age range: 45-86 years old) and 40 patients with $\mathrm{AD}$ (age range: 45-90 years old). The Alzheimer patients were chosen from an elderly nursing home in Gorgan, Iran. Patients with type 2 diabetes mellitus, liver disease, renal failure and chronic infectious disease were not included in this study.

*Corresponding author: Abdoljalal Marjani, Metabolic Disorders Research Center, Department of Biochemistry and Biophysics, Faculty of Medicine Golestan University of Medical Sciences, Gorgan, Golestan Province, Iran, Tel: +981714421651; E-mail: abdoljalal@yahoo.com

Received October 25, 2016; Accepted October 28, 2016; Published November 08,2016

Citation: Hakimi S, Marjani A, Khajeniazi S (2016) Serum Level and Genetic Polymorphism of Secretary Phospholipase A2-IIA in Alzheimer's Disease. Med Chem (Los Angeles) 6: 670-673. doi:10.4172/2161-0444.1000413

Copyright: @ 2016 Hakimi S, et al. This is an open-access article distributed unde the terms of the Creative Commons Attribution License, which permits unrestricted use, distribution, and reproduction in any medium, provided the original author and source are credited. 
Two groups were matched according to age and gender. The Ethics Committees of Deputy of Research at Golestan University of Medical Sciences was approved our study. Mini Mental State Examination (MMSE) was used by a neurologist to diagnose Alzheimer's patients. Written agreement was achieved from relatives of all subjects. Five ml blood samples were collected in tubes with EDTA and serum tubes for determination of secretary phospholipase A2-IIA genotypes and levels, respectively. Serum levels of enzyme were determined by the method sPLA $_{2}$ (human Type IIA) EIA Kit (Cayman Chemical Company, Item No. 585000, USA) by using ELISA technique at the Metabolic Disorders Research Center, Gorgan Faculty of Medicine.

\section{Amplification Refractory Mutation System (ARMS) and Polymerase Chain Reaction (PCR) analysis (ARMS-PCR)}

White blood cells were used for DNA extraction by salting-out method [26]. Extracted DNA was dissolved by sterilized distilled water. The ARMS-PCR techniques were used to determine the polymorphisms of SPLAII2a -763C $>\mathrm{G}$ using Genetix CG palmthermocycler (India). Amplification was performed for DNA fragment containing polymorphic site $-763 \mathrm{C}>\mathrm{G}$. For PCR amplification, we were performed using the following primers:

\section{Reverse primer $_{1}\left(\mathrm{R}_{1}\right):$ ' '-CTCCTGCTCCCCTTAAATAGCTG-3'}

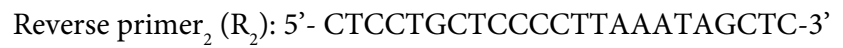

\section{Forward primer: 5'-AAAGACTGCAAAACTGCCTGAAA-3'}

A $25 \mu \mathrm{L}$ reaction mixture was prepared for the ARMS $\mathrm{R}_{1}-\mathrm{PCR}$ process including: $2.5 \mu \mathrm{L}$ PCR buffer, $0.5 \mu \mathrm{L} \mathrm{MgCl}_{2}$ (100 mM, Bioron), $0.5 \mu \mathrm{L}$ deoxyribonucleotide triphosphate (dNTP, $10 \mathrm{mM}$, Bioron), $1 \mu \mathrm{L}$ Reverse 1 primer (10 PM), $1 \mu \mathrm{L}$ Forward primer (10 PM), $0.3 \mu \mathrm{L}$ Taq polymerase ( $5 \mathrm{U} / \mathrm{ml}$, Bioron), $3 \mu \mathrm{L}$ genomic DNA $(20 \mathrm{ng})$ and $16.2 \mu \mathrm{L}$ double distillated water.

Preparation of $25 \mu \mathrm{L}$ reaction mixture for the ARMS $\mathrm{R}_{2}-\mathrm{PCR}$ process was the same except for concentration of $\mathrm{MgCl}_{2}(0.62 \mu \mathrm{L}, 100$ $\mathrm{mM})$ and double distillated water $(16.08 \mu \mathrm{L})$.

The ARMS- $\mathrm{R}_{1}$-PCR amplification conditions included initial denaturation $\left(45 \mathrm{cycles}\right.$ at $95^{\circ} \mathrm{C}$ for 3 minutes), denaturation (at $95^{\circ} \mathrm{C}$ for 30 seconds), annealing (at $66^{\circ} \mathrm{C}$ for 30 seconds), extension (at $72^{\circ} \mathrm{C}$ for 45 seconds) and final extension (at $72^{\circ} \mathrm{C}$ for 7 minutes).

The ARMS () $\mathrm{R}_{2}$-PCR amplification conditions was the same as ARMS $\mathrm{R}_{1}$-PCR amplification conditions except for annealing (at $62^{\circ} \mathrm{C}$ for 30 seconds). Figure 1 shows the PCR products. Agarose gel (1.5\%) stained with Cyber Safe $(0.2 \mu \mathrm{L})$ was used for electrophoresis of DNA fragments (Apelex, France). The bands were detected using a Polaroid Gel Camera.

\section{Statistical analysis}

Chi-squared test was used to compare overall allele and genotype frequencies of the polymorphism between Alzheimer patients and controls using the statistical software version 16 (SPSS Inc., Chicago, IL, USA). Data are shown as percentage and means \pm standard deviation (SD). Independent $t$-test was performed to compare Alzheimer patients and the control group. $\mathrm{P}$ value $<0.05$ was considered as statistically significant.

\section{Results}

The genotypic and allelic distribution of the sPLA2 gene is shown on the Table 1. There was significant difference in genotypic and allelic frequencies of enzyme between Alzheimer patients and controls. In

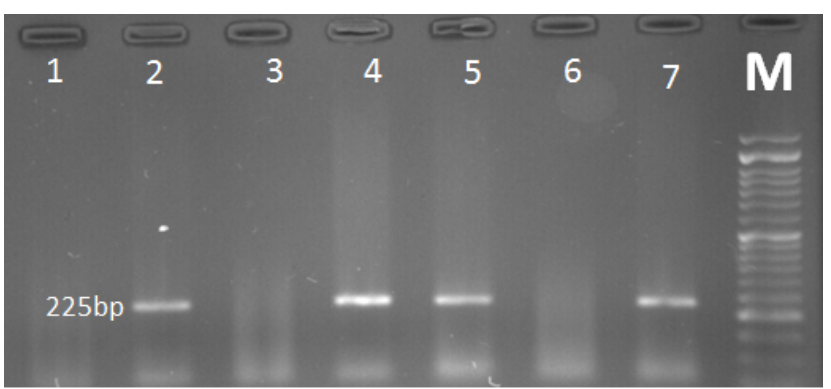

Figure 1: Determination of undigested SPLAII2a -763C>G polymorphism by PCR-RFLP. DNA ladder (50 bp) was loaded into well M; Well 1 was negative control; Wells 2 and 3 were GG; Wells 4 and 5 were CG and Wells 6 and 7 were CC DNA fragments with $225 \mathrm{bp}$.

Alzheimer patients, the CC genotype and C allele frequencies of enzyme were significantly lower while the CG and GG genotypes and G allele frequencies of enzyme were significantly higher than control groups. The mean concentration and mean rank of genotypic distribution of the sPLA2 gene are shown on the Table 2. The mean concentration and mean rank of enzyme for CC genotype significantly were lower while the mean concentration and mean rank of enzyme for CG and GG genotypes of enzyme were significantly higher than control groups.

\section{Discussion}

Etiology of $\mathrm{AD}$ seems to be complicated. In this study, we researched the concentration of and genetic polymorphisms of sPLA2 in Alzheimer's patients and compared with control group. The basic finding of this study was that the level and polymorphism of sPLA2 were significantly different in Alzheimer's patients in comparison to controls. Our results indicated those of some studies which showed that the levels of mutated enzyme (With high CG and GG genotypes levels) are significantly increased in $\mathrm{AD}$ [27]. Some studies have indicated that the variation of sPLA IIA polymorphism is associated with the levels of this enzyme [27]. Our study reveals that there is association between higher sPLA2-IIA levels with expression of the $\mathrm{C}$ allele. Our findings showed that the allele $\mathrm{C}$ may be a protective genetic factor to $\mathrm{AD}$. There are significant difference in the frequency of the $\mathrm{C}$ and $\mathrm{G}$ alleles between Alzheimer's patients and controls. It has reported that mRNA is shown for expression of the sPLA2-IIA in the brain [28] and sPLA2 type IIA activation may cause to neuronal death [29] and depressive disorder [30]. Many studies have shown that there is a diversity of PLA2 enzymes in human. Six isoforms of the sPLA2 enzyme were identified in the brain (sPLA2-IIA, sPLA2-IIC, sPLA2-IIE, sPLA2-V, sPLA2-X and sPLA2-XII) $[7,8,31,32]$. This diversity of enzymes may show the distinct functional roles of specific isoforms. Some studies have shown a decrease in the activity of PLA2 in the brain of subjects with AD. Decreased activity of total PLA2 was observed more in the postmortem parietal and frontal cortices of $\mathrm{AD}$ subjects. It was reported that there was a correlation between decreased level of PLA2 and the severity of dementia $[23,24]$. Studies on AD patients have shown that brain PLA2 phospholipases A2 are changed in different ways. These alterations may have different functional implications in Alzheimer disease [29]. It has been also revealed that activity of cPLA2 and iPLA2 enzymes decreased in postmortem brain $[23,24,33,34]$ and cerebrospinal fluid [14] of patients with AD. Some other studies have reported that there are increased level of secreted PLA2 (sPLA2) in cerebrospinal fluid of patients with $\mathrm{AD}$ [15]. Among all brain tissue PLA2 isoforms, the functional roles of specific isoforms of the sPLA2 group have been better described. The recent study has shown that PLA2-IIA is the only 
Citation: Hakimi S, Marjani A, Khajeniazi S (2016) Serum Level and Genetic Polymorphism of Secretary Phospholipase A2-IIA in Alzheimer's Disease. Med Chem (Los Angeles) 6: 670-673. doi:10.4172/2161-0444.1000413

\begin{tabular}{|c|c|c|c|c|c|c|}
\hline \multirow{2}{*}{ Polymorphism } & \multirow{2}{*}{$\begin{array}{c}\text { Genotypes } \\
n=80\end{array}$} & \multicolumn{2}{|c|}{ Frequency } & \multirow{2}{*}{$\begin{array}{c}\text { Alleles } \\
n=160\end{array}$} & \multicolumn{2}{|c|}{ Frequency } \\
\hline & & $\mathrm{n}$ & $\%$ & & $\mathbf{n}$ & $\%$ \\
\hline $\begin{array}{l}\text { SPLAll2a }-763 C>G \\
\text { (Alzheimer patients) } \\
\quad(n=40)\end{array}$ & $\begin{array}{l}\mathrm{CC} \\
\mathrm{CG} \\
\mathrm{GG}\end{array}$ & $\begin{array}{l}10 \\
20 \\
10\end{array}$ & $\begin{array}{l}25 \\
50 \\
25\end{array}$ & $\begin{array}{l}\text { C } \\
\text { G }\end{array}$ & $\begin{array}{l}40 \\
40\end{array}$ & $\begin{array}{l}50 \\
50\end{array}$ \\
\hline $\begin{array}{c}\text { SPLAII2a }-763 C>G \\
(\text { Control }) \\
(n=40)\end{array}$ & $\begin{array}{l}\text { CC } \\
\text { CG } \\
\text { GG }\end{array}$ & $\begin{array}{c}34 \\
3 \\
3\end{array}$ & $\begin{array}{l}85 \\
7.5 \\
7.5\end{array}$ & $\begin{array}{l}\text { C } \\
\text { G }\end{array}$ & $\begin{array}{l}71 \\
9\end{array}$ & $\begin{array}{l}88.75 \\
11.25\end{array}$ \\
\hline$P$-value & & & & & & \\
\hline
\end{tabular}

Data are shown as percentage, examined by the $X^{2}$ test. $P$ value $<0.05$ were considered significant for genotypes of enzyme between two groups. Table 1: Genotype and allele frequency of SPLAll2a polymorphism in Alzheimer's patients and control group.

\begin{tabular}{|c|c|c|c|}
\hline Parameters & \multicolumn{2}{|c|}{$\begin{array}{c}\text { Alzheimer's patients } \\
\text { (n=40) }\end{array}$} & $\begin{array}{c}\text { Control group } \\
\text { (n=40) }\end{array}$ \\
\hline Genotypes & Mean Concentration (pgr/mL) & Mean Rank & Mean Concentration (pgr/mL) \\
\hline CC & $80.25 \pm 31.04$ & 157.87 & $113.89 \pm 28.80$ \\
\hline CG & $238.12 \pm 88.7$ & 598.82. & $215.36 \pm 59.63$ \\
\hline GG & $679.07 \pm 363.59$ & 440.94 & 350.36 \\
\hline
\end{tabular}

Data are shown as mean concentration and mean rank, examined by Independent sample $t$ test. $\mathrm{P}$ value $<0.05$ were considered significant for genotypes and alleles of enzyme between two groups.

Table 2: The mean concentration and mean rank of genotypic distribution of the sPLA2 gene in Alzheimer's patients and control group.

isoform detectable in the blood stream, especially under pathological conditions [35]. Thus, it is also important to investigate the level and activity of sPLA2 isoforms. These enzymes may show a significant role in neuronal differentiation, Survival and neuronal death [36-39]. Studies on the rat model have revealed upregulation of sPLA2-IIA enzyme in the brain in reaction to injury and inflammation [40]. It has been shown that in rat spinal cord injury, expression of sPLA2IIA increased [41-43]. Study on brains of human with AD indicated that sPLA2-IIA mRNA expression in the hippocampal region of Alzheimer patients increased when compared to age-matched, nondemented controls [9]. These present results suggest that there are a variation between the expression of sPLA2-IIA in Alzheimer patients and the risk of AD. Some studies have shown that sPLA2-IIA [44] produces reactive oxygen species (ROS). This may cause membrane lipid peroxidation and impair the integrity of neuronal membranes. Elevation of oxidative stress in an early event in AD causes reduction in disease progression and formation of lesions [45]. Studies have shown that ROS is produced during the metabolism of arachidonic acid [44]. Some other studies have been reported that SPLA2-IIA causes apoptosis in neurons and contributes to neurodegeneration in the ischemic brain [46-48]. Because of various effects of sPLA2-IIA on cells, it needs to investigate the mechanisms of this enzyme.

\section{Conclusion}

Genetic investigations show a possibility for $\mathrm{AD}$ studying. The effect of different gene polymorphisms for the incident of $\mathrm{AD}$ is still unclear. We determined gene polymorphisms of sPLA2-IIA which may relate to $\mathrm{AD}$. It can be suggest that a single or combination of gene polymorphisms have possible effect for development of AD. Further studies are needed to research the functional roles of sPLA2-IIA in the context of $\mathrm{AD}$.

\section{Funding}

This work has been supported by the Research Deputy of Golestan University of Medical Science.

\section{Declaration of Conflicting of Interests}

The authors declared no conflicts of interest.

\section{Acknowledgements}

The authors would like to thank the Research Deputy of Golestan University of Medical Sciences for financial support. This research project was derived from MSc Thesis in Clinical Biochemistry. The corresponding author wishes to thank Mrs Safoura Hakimi for her sincere help.

\section{References}

1. Prince M, Jackson J (2009) World Alzheimer Report. London, England: Alzheimer's Disease International.

2. Desikan RS, Cabral HJ, Settecase F, Christopher PH, William PD, et al (2010) Automated MRI measures predict progression to Alzheimer's disease. Neurobiol Aging 31: 1364-1374

3. Wisniewski T, Frangione B (1996) Molecular biology of brain aging and neurodegenerative disorders. Acta Neurobiol Exp (Wars) 56: 267-279.

4. Yagami T (2006) Cerebral arachidonate cascade in dementia: Alzheimer's disease and vascular dementia. Curr Neuropharmacol 4: 87-100.

5. Burke JE, Dennis EA (2009) Phospholipase A2 structure/ function, mechanism, and signaling. J. Lipid Res. 50: S237-S242.

6. Goracci G, Ferrini M, Nardicchi V (2010) Low molecular weight phospholipases A2 in mammalian brain and neural cells: roles in functions and dysfunctions. Mol Neurobiol 41: 274-289.

7. Suzuki N, Ishizaki J, Yokota Y, Higashino K, Ono T, et al. (2000) Structures, enzymatic properties, and expression of novel human and mouse secretory phospholipase A(2)s. J Biol Chem 275: 5785-579.

8. Molloy GY, Rattray M, Williams RJ (1998) Genes encoding multiple forms of phospholipase A2 are expressed in rat brain. Neurosci Lett 258: 139-142.

9. Moses GS, Jensen MD, Lue LF, Walker DG, Sun AY, et al. (2006) Secretory PLA2-IIA: a new inflammatory factor for Alzheimer's disease. J Neuroinflammation 3: 28

10. Pruzanski W, Keystone EC, Sternby B, Bombardier C, Snow KM, et al. (1988) Serum phospholipase A2 correlates with disease activity in rheumatoid arthritis. J Rheumatol 15: 1351-1355.

11. Oorni K, Kovanen PT (2009) Lipoprotein modification by secretory phospholipase $A(2)$ enzymes contributes to the initiation and progression of atherosclerosis. Curr Opin Lipidol 20: 421-427. 
Citation: Hakimi S, Marjani A, Khajeniazi S (2016) Serum Level and Genetic Polymorphism of Secretary Phospholipase A2-IIA in Alzheimer's Disease. Med Chem (Los Angeles) 6: 670-673. doi:10.4172/2161-0444.1000413

12. Henderson WR Jr, Oslund RC, Bollinger JG, Ye X, Tien YT, et al. (2011) Blockade of human group $X$ secreted phospholipase A2 (GX-sPLA2)-induced airway inflammation and hyperresponsiveness in a mouse asthma model by a selective GX-sPLA2 inhibitor. J Biol Chem 286: 28049-28055.

13. Mallat Z, Lambeau G, Tedgui A (2010) Lipoprotein-associated and secreted phospholipases $A$ in cardiovascular disease: roles as biological effectors and biomarkers. Circulation 122: 2183-2200.

14. Smesny S, Stein S, Willhardt I, Lasch J, Sauer H (2008) Decreased phospholipase A2 activity in cerebrospinal fluid of patients with dementia. J Neural Transm 115: 1173-1179.

15. Chalbot S, Zetterberg H, Blennow K, Fladby T, Grundke-lqbal I, et al. (2009) Cerebrospinal fluid secretory $\mathrm{Ca} 2+$-dependent phospholipase A2 activity is increased in Alzheimer disease. Clin Chem 55: 2171-2179.

16. Cordeiro Q, Noguti R, Bottino CM, Vallada H (2010) Study of association between genetic polymorphisms of phospholipase A2 enzymes and Alzheimer's disease. Arq Neuropsiquiatr 68: 189-193.

17. Masuda S, Yamamoto K, Hirabayashi T, Ishikawa Y, Ishii T, et al. (2008) Human group III secreted phospholipase A2 promotes neuronal outgrowth and survival. Biochem J 409: 429-438.

18. Sanchez-Mejia RO, Newman JW, Toh S, Yu GQ, Zhou Y, et al. (2008) Phospholipase A2 reduction ameliorates cognitive deficits in a mouse model of Alzheimer's disease. Nat Neurosci 11: 1311-1318.

19. Chiricozzi E, Fernandez-Fernandez S, Nardicchi V, Almeida A, Bolaños JP, et al. (2010) Group IIA secretory phospholipase A2 (GIIA) mediates apoptotic death during NMDA receptor activation in rat primary cortical neurons. J Neurochem 112: 1574-1583.

20. Fernandez LL, Scheibe RM (2005) Is MTHFR polymorphism a risk factor for Alzheimer's disease like APOE? Arq Neuropsiquiatr 63: 1-6.

21. Silva VC, Ramos FJ, Freitas EM (2006) Alzheimer's disease in Brazilian elderly has a relation with homocysteine but not with MTHFR polymorphisms. Arq Neuropsiquiatr 64: 941-945

22. Barbosa NR, Junqueira R, Vallada H, Gattaz WF (2007) Association between Banl genotype and increased phospholipase A2 activity in schizophrenia. Eur Arch Psychiatry Clin Neurosci 257: 340-343.

23. Gattaz WF, Maras A, Cairns NJ, Levy R, Förstl H (1995) Decresead phospholipase A2 activity in Alzheimer brain. Biol Psychiatry 37: 13-17.

24. Gattaz WF, Cairns NJ, Levy R, Forstl H, Braus DF, et al. (1996) Decreased phospholipase A2 activity in the brain and in platelets of patients with Alzheimer's disease. Eur Arch Psychiatry Clin Neurosci 246: 129-131.

25. Gattaz WF, Forlenza OV, Talib LL, Barbosa NR, Bottino CMC (2004) Platelet phospholipase A2 activity in Alzheimer's disease and mild cognitive impairment. J Neural Transm 111: 591-601.

26. Miller SA, Dykes DD, Polesky HF (1988) A simple salting out procedure for extracting DNA from human nucleated cells. Nucleic Acids Res 16: 1215.

27. Wootton PT, Drenos F, Cooper JA, Thompson SR, Stephens JW, et al. (2006) Tagging-SNP haplotype analysis of the secretory PLA2lla gene PLA2G2A shows strong association with serum levels of sPLA2lla: results from the UDACS study. Hum Mol Genet 15: 355-361.

28. Sun GY, Xu J, Jensen MD, Simonyi A (2004) Phospholipase A2 in the central nervous system: implications for neurodegenerative diseases. Journal of Lipid Research 45: 205-213.

29. Schaeffer EL, da Silva ER, Novaes Bde A, Skaf HD, Gattaz WF (2010) Differential roles of phospholipasesA2 in neuronal death and neurogenesis: implications for Alzheimer disease. Progress in Neuro-Psychopharmacology \& Biological Psychiatry 34: 1381-1389.

30. Maes M, Galecki P, Chang YS, Berk MA (2011) Review on the oxidative and nitrosative stress (O\&NS) pathways in major depression and their possible contribution to the (neuro)degenerative processes in that illness. Progress in Neuro-Psychopharmacology \& Biological Psychiatry 35: 676-692.

31. Chen J, Engle SJ, Seilhamer JJ, Tischfield JA (1994) Cloning and recombinan expression of a novel human low molecular weight $\mathrm{Ca}(2+)$-dependent phospholipase A2. J Biol Chem 269: 2365-2368.

32. Gelb MH, Valentin E, Ghomashchi F, Lazdunski M, Lambeau G (2000) Cloning and recombinant expression of a structurally novel human secreted phospholipase A2. J Biol Chem 275: 39823-39826.
33. Ross BM, Moszczynska A, Erlich J, Kish SJ (1998) Phospholipid-metabolizing enzymes in Alzheimer's disease: increased lysophospholipid acyltransferase activity and decreased phospholipase A2 activity. J Neurochem 70: 786-793.

34. Talbot K, Young RA, Jolly-Tornetta C, Lee VM, Trojanowski JQ, et al. (2000) A frontal variant of Alzheimer's disease exhibits decreased calcium-independent phospholipase A2 activity in the prefrontal cortex. Neurochem Int 37: 17-31.

35. Murakami M, Sato H, Miki Y, Yamamoto K, Taketomi Y (2015) A new era of secreted phospholipase A2. Journal of lipid research 56: 1248-1261.

36. Arioka M, Cheon SH, Ikeno Y, Nakashima S, Kitamoto K (2005) A nove neurotrophic role of secretory phospholipases A2 for cerebellar granule neurons. FEBS Lett 579: 2693-2701.

37. Ikeno Y, Konno N, Cheon SH, Bolchi A, Ottonello S, et al. (2005) Secretory phospholipases A2 induce neurite outgrowth in $\mathrm{PC} 12$ cells through lysophosphatidylcholine generation and activation of G2A receptor. J Biol Chem 280: 28044-2852.

38. Masuda S, Murakami M, Takanezawa Y, Aoki J, Arai H, et al. (2005) Neuronal expression and neuritogenic action of group $X$ secreted phospholipase $A 2$. J Biol Chem 280: 23203-2314.

39. Thomas G, Bertrand F, Saunier B (2000) The differential regulation of group II(A) and group $\mathrm{V}$ low molecular weight phospholipases $A(2)$ in cultured rat astrocytes. J Biol Chem 275: 10876-10886.

40. Adibhatla RM, Hatcher JF (2008) Altered lipid metabolism in brain injury and disorders. Subcell Biochem 49: 241-268.

41. Liu NK, Xu XM (2010) Phospholipase A2 and its molecular mechanism after spinal cord injury. Mol Neurobiol 41: 197-205.

42. Titsworth WL, Cheng $X, \mathrm{Ke} Y$ (2009) Differential expression of sPLA2 following spinal cord injury and a functional role for SPLA2-IIA in mediating oligodendrocyte death. Glia 57: 1521-1537.

43. Titsworth WL, Liu NK, Xu XM (2008) Role of secretory phospholipase a(2) in CNS inflammation: implications in traumatic spinal cord injury. CNS Neuro Disord Drug Targets 7: 254-269.

44. Yagami T, Ueda K, Asakura K, Nakazato H, Hata S (2003) Human group IIA secretory phospholipase $\mathrm{A} 2$ potentiates $\mathrm{Ca} 2+$ influx through L-type voltagesensitive Ca2+ channels in cultured rat cortical neurons. J Neurochem 85: 749758.

45. Nunomura A, Perry G, Aliev G, Hirai K, Takeda A, et al. (2001) Oxidative damage is the earliest event in Alzheimer disease. J Neuropathol Exp Neurol 60: 759-767.

46. Yagami T, Ueda K, Sakaeda T, Okamura N, Nakazato H, et al. (2005) Effects of an endothelin B receptor agonist on secretory phospholipase A2-IIA-induced apoptosis in cortical neurons. Neuropharmacology 48: 291-300.

47. Chiricozzi E, Fernandez-Fernandez S, Nardicchi V, Almeida A, Bolaños JP et al. (2010) Group IIA secretary phospholipase A2 (GIIA) mediates apoptotic death during NMDA receptor activation in rat primary cortical neurons. J Neurochem 112: 1574-1583.

48. Yagami T, Ueda K, Asakura K, Hata S, Kuroda T, et al. (2002) Human group IIA secretory phospholipase A2 induces neuronal cell death via apoptosis. Mol Pharmacol 61: 114-126. 